\title{
Defoliator Pest to Caboclos and Gourmet Food to the Suruí Indians: Contrasting Amazonian Perspectives of Lusura sp. Caterpillars
}

\author{
Carlos E. A. Coimbra, Jr. \\ Author address: Escola Nacional de Saúde Pública, Fundação Oswaldo Cruz, Rua Leopoldo Bulhões 1480, Rio de Janeiro, \\ 21041-210, Brazil. \\ coimbra@ensp.fiocruz.br
}

Received: September 10, 2011

Volume: 2:56-60

Published: August 9, 2012

(C) 2012 Society of Ethnobiology

\begin{abstract}
The use of a Lusura sp. (Lepidoptera: Notodontidae) caterpillar as food by the Surui Indians from the southwestern Brazilian Amazon is reported in the context of family collecting excursions during arboreal infestations observed in July-August 1983. This caterpillar erupts in very large numbers on Brazil nut trees, denuding them of foliage. The paper calls attention to contrasting views about these caterpillar infestations among different inhabitants of the forest, being considered a desirable food delicacy by the Surui and a destructive pest defoliator by caboclos.
\end{abstract}

Key Words: Amazonia, Indigenous peoples, Brazil nut tree, Insects as food, Ethnoentomology

Reading a recently published article in Biotropica brought back memories of my first years of fieldwork among the Suruí Indians in Rondônia, Brazil, in the 1980s. The article (Haugaasen 2009) describes the defoliating action of the moth larva Lusura altrix Stoll (Lepidoptera: Notodontidae) on the canopy of the Brazil nut tree (Bertholletia excelsa Bonpl. Lecythidaceae) ${ }^{1}$ (Figure 1). According to the author, attacked trees are completely stripped of their leaves. Based on testimonies collected among the local caboclo ${ }^{2}$ population, the voracity of the caterpillars is said to impact the flowering and subsequent fruiting of the tree, causing negative economic consequences for the commercial production of Brazil nuts, with harvests reduced by more than $60 \%$.

During my stays among the Suruí ${ }^{3}$ I would often accompany groups of men on hunts and whole families during collecting activities. Commonly, family excursions contemplated multiple objectives, such as collecting seasonal fruits, honey, heart-of-palms, bird eggs, medicinal plants, and insect larvae, among other items. Some of these activities could last several days and involved camping in the forest. In relation to the insects, beetle larvae from the Bruchidae and Curculionidae families immediately captured my interest for their importance in the Suruí diet. Depending on the species, these were collected from babaçu or tucumã coconuts (Attalea speciosa Mart. ex
Spreng. Arecaceae and Astrocaryum aculeatum G. Mey. Arecaceae) or from downed logs of the jaracatia tree [Jacaratia digitata (Poepp. \& Endl.) Solms Caricaceae], as I described previously (Coimbra Jr. 1984).

During the months of July and August 1983, something happened that was without precedence in my experience. Entire family groups turned their attention to caterpillar outbreaks high in the canopies of Brazil nut trees. These ecological commotions became visually perceptible from a distance as clusters of trees rapidly lost their leaves, causing them to stand out in their bareness as gaps in the green shades that dominate the Amazonian canopy. Initially I had no idea what might be happening with these trees, although the signs were more than evident for the Suruí. Upon noticing the first indications, family groups organized excursions into the forest to accompany the outbreaks. They went specifically looking for Brazil nut trees with no leaves since it was there that they would find thousands of the caterpillars they called mamnég-éy.

On that first occasion, I accompanied several family groups to areas in the forest surrounding the village with concentrations of Brazil nut trees. What I witnessed there was striking, as the explosion of caterpillars reaching the last instar of larval development descended from the canopy along the trunks of the trees. Under the canopy of these trees, little balls of caterpillar feces rained down on our 

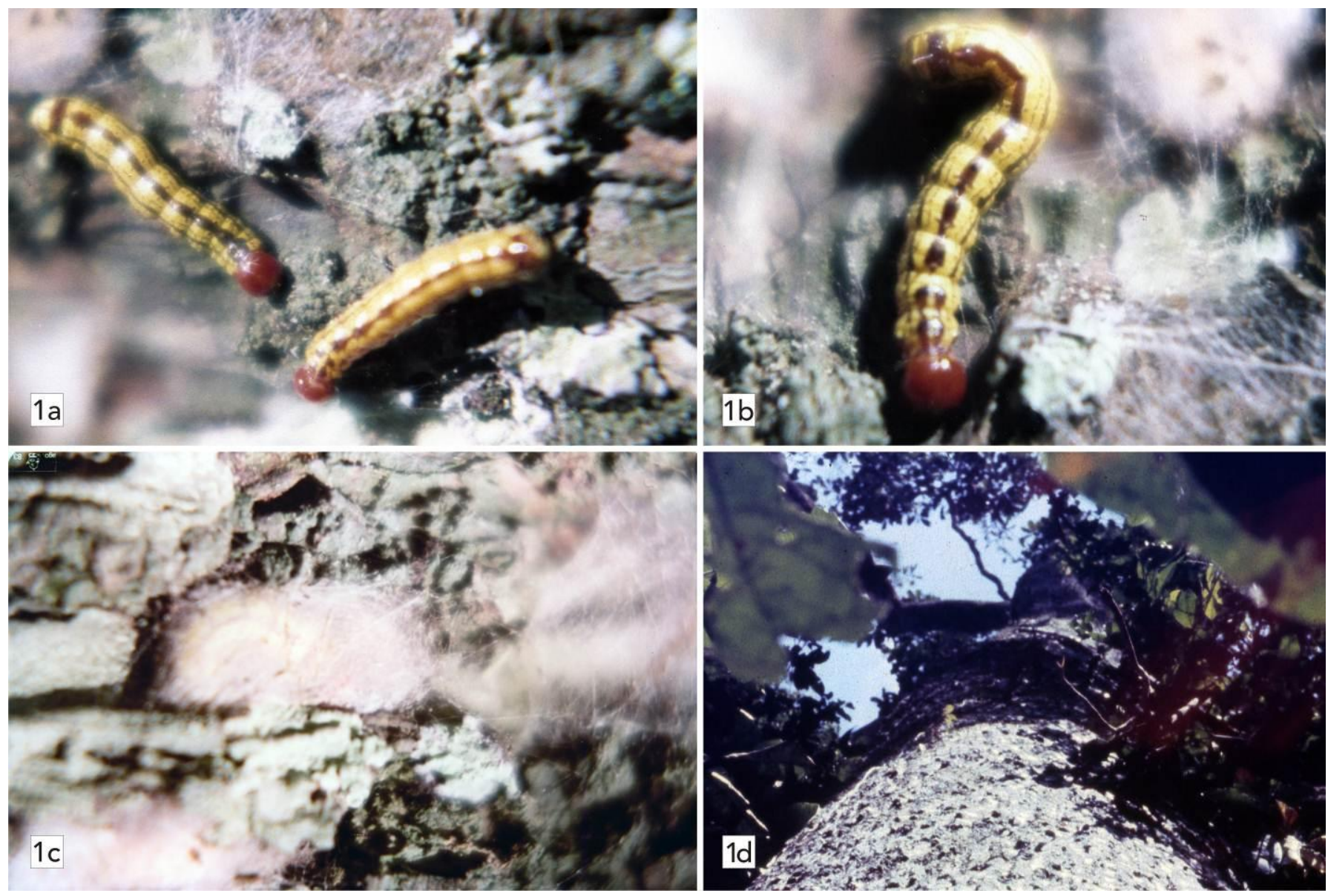

Figure 1. (1a-1b) Lusura sp. caterpillars on the trunk of a Brazil nut tree (note the white filaments, indicating the beginning of cocoon production during the last stage of larval development); (1c) Lusura sp. cocoon adhering to the trunk of a tree; (1d) upward view of a Brazil nut trunk infested with Lusura sp. caterpillars (note the canopy is almost completely defoliated due to the caterpillar attack, permitting an otherwise impossible view of the blue sky where there was once dense foliage). Photographs by Carlos Coimbra Jr., Sete de Setembro Indigenous Reserve, Rondônia, Brazil, 1983.

heads. As the caterpillars descended, they accumulated on the lower third of the tree trunks where they pupated in the cracks and crevices of the bark, forming around them little cocoons of white silk that adhered to the tree. The situated cocoons were so numerous that there was practically no room for the flow of caterpillars that continued to descend from the canopy. Consequently, they fell to the ground as though they were pushed from the surface of the trunk, but soon climbed back up any nearby branch or tree in search of adequate space to pupate.

Given the huge number of caterpillars, the greatest challenge for the Suruí was to collect them before they became pupae. The gourmet delicacy consisted of eating the still-soft larvae, recently taken from new cocoons before they pupated and hardened. Whole family groups, including children and elders, undertook this collecting activity, which often lasted between three to four days. In order to reach caterpillars in the highest parts of the trunk, some men built scaffolds of poles bound with vines. Back in the village, full baskets carried by the women were emptied as they arrived and the caterpillars were placed in deep clay pots to toast, after which they were eaten plain, accompanied with dry popped corn kernels, or mixed with toasted cornmeal, the latter two derived from native Suruí varieties. I did not observe any restrictions in the consumption of these caterpillars - children and adults of both genders were equally enthusiastic to eat this delicacy.

According to the Suruí these esteemed eruptions of mamnég-éy larvae only occurred every three or four years. They also told me that similar defoliating events were occasionally caused by other types of caterpillars, 
also edible, in different tree species, such as caucho (Castilla ulei Warb. Moraceae) and breu [Tetragastris altissima (Aubl.) Swart Burseraceae]. However, I didn't have the opportunity to observe these other caterpillar taxa. Considering the rarity of these events, caterpillars cannot be considered a major source of proteins or other nutrients in the routine Suruí diet.

In order to identify the mamnég-éy insect, I collected a small number of caterpillars that were about to pupate and put them in a cardboard box covered with screen in the village. After two days, all of them had adhered to the walls of the box and covered themselves in white silk. Twelve days passed before the first cocoons hatched, giving rise to greyish nocturnal moths. As soon as they hatched, adult moths were placed in flasks with sulfuric ether vapor and immediately mounted with entomological pins. Unfortunately, only four moths hatched and, despite my best efforts, while I was still in the field the mounted specimens were attacked and partially destroyed by small ants that roamed in search of everything organic in the plank hut where I hung my hammock. The larvae specimens were preserved in $70 \%$ ethyl alcohol and taken to the University of Brasilia, where I studied at the time. They were identified with the generous help of Dr. David Ross
Gifford, specialist in neotropical lepidopterans and professor at the Institute of Biological Sciences. The circumstances of their collection made identification difficult but not impossible.

From the entomological point of view, the mamnégéy caterpillars pertain to the Lusura genus (Notodontidae). It is also likely that they belong to the altrix species, considering the morphological similarities between the specimens I collected among the Suruí and this species, which has an ample distribution in the south-central portion of the Amazon, having been observed in Brazil nut collecting areas in caboclo communities located in the region of the Purús River in Amazonas state (Haugaasen 2009), the Madeira River in Rondônia state (Santos 2011), and the Bolivian lowlands (Hurtado 2010).

In a review of the anthropological and ethnobiological literature about insect foods among indigenous peoples in Brazil, Costa-Neto and RamosElorduy (2006) encountered references to 135 types of insects pertaining to nine orders. Of these, 95 taxa were classified to the species level. Only $4 \%$ of these species were classified in the order Lepidoptera; almost three quarters of the total cited in the literature pertain to the orders Hymenoptera (63\%) and Coleoptera (16\%).

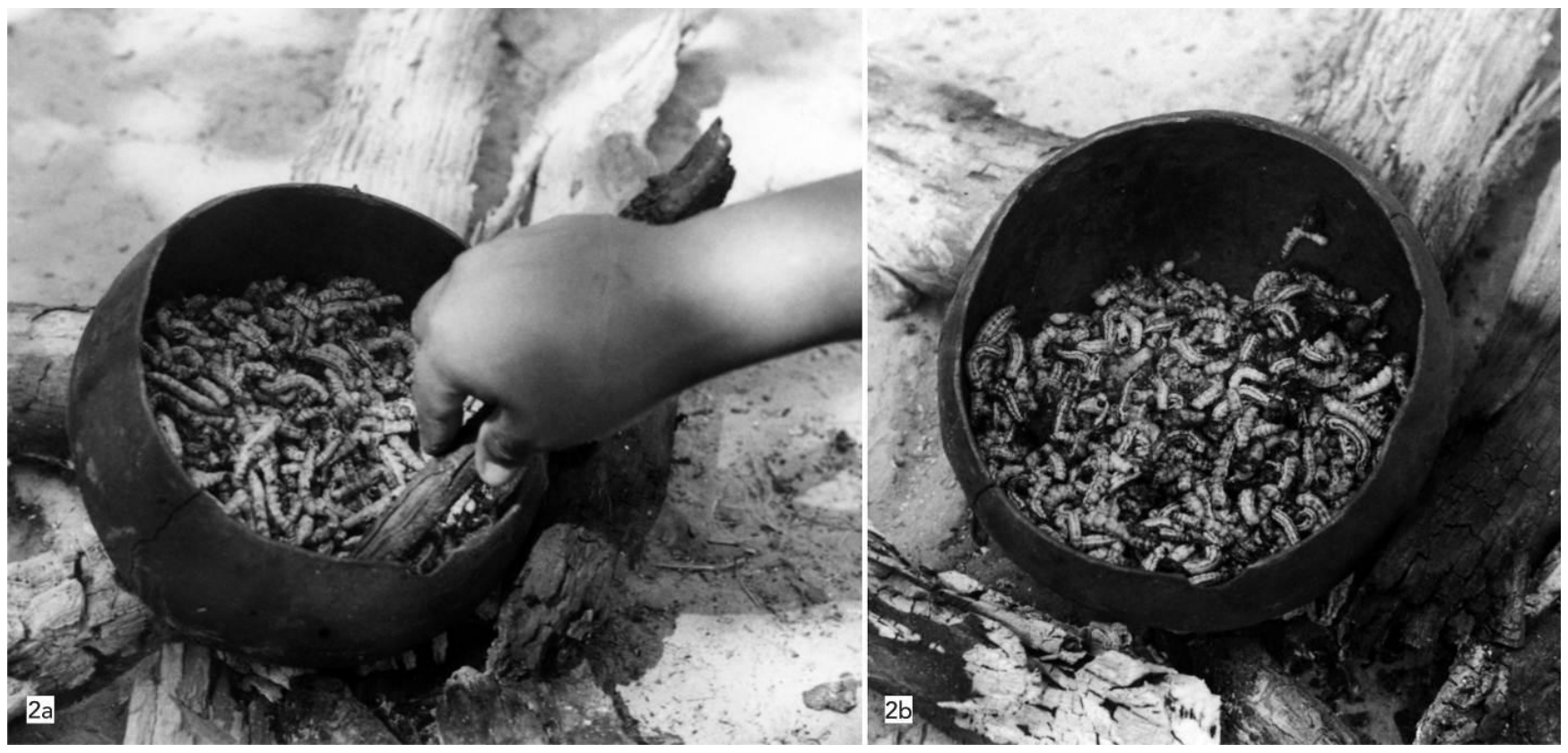

Figure 2. (2a-2b) Suruí woman toasting Lusura sp. caterpillars in a traditional clay pot. The caterpillars were placed in a preheated pot without added oil and continually stirred. At the end of the cooking process, the caterpillars became crispy and the equivalent of several tablespoons of fat, which came from the caterpillars as they cooked, could be seen at the base of the pot. This fat was often used by the Suruí in, for example, preparing red paint from urucu seeds (Bixa Orellana L. Bixaceae). Photograph by Carlos Coimbra Jr., Sete de Setembro Indigenous Reserve, Rondônia, Brazil, 1983. 
Also according to these authors, the Lepidoptera species identified as food items used by different indigenous peoples in Brazil pertain to the families Hepialidae, Morphidae, Nymphalidae, Phalaenidae, and Pyralidae. Taking into account literature reviews addressing indigenous groups throughout Amazonia, this list also includes the families Brassolidae, Castniidae, Noctuidae, Saturniidae, and Sphingidae (Araujo and Beserra 2007; Paoletti and Dufour 2005). It is important to stress that this list certainly does not express the entire reality of Lepidoptera larvae as human food among indigenous groups in the Amazon. The ethnographic literature for the region is full of references to edible caterpillars without any information regarding genus or species.

The only reference in the literature to an indigenous group consuming a caterpillar from the Notodontidae family is a study by Dufour (1987) regarding Tukano groups in the northwest Amazon. However, in this case there was no identification of the insect's genus. It is unlikely that the caterpillar consumed by the Tukano is the same as that I observed among the Suruí (Lusura sp.) because Dufour described them as feeding on Inga spp. leaves, a large genus of neotropical trees in the Fabaceae family. The Notodontidae family includes over 1,300 species in the neotropics, the majority of which have extremely high larval host specificity (Weller 1992).

In a previous article, I addressed the question of the pest/food opposition in discussing beetle larvae that develop on palm trees, especially those pertaining to the Curculionidae family. For entomologists and agronomists, these are considered pests that attack various palm species of commercial interest, particularly coconut (Cocos nucifera L. Arecaceae) and oil palm (Elaeis guineensis Jacq. Arecaceae), and are combatted chemically. For the Suruí, however, they constitute an extremely valued food (Coimbra Jr. and Santos 1993) (Figure 2). Similarly contrasting views regarding reptiles as beneficial and/or as pests have been documented for other rural Brazilian communities (see review by Alves et al. 2011).

Returning to the subject of my opening paragraph, the article by T. Haugaasen (2009) caught my attention precisely because in highlighting the negative aspects of Brazil nut trees defoliation by Lusura sp. larvae in a caboclo community in the lower Rio Purús region of Brazil, the author made apparent the potentially contrastive cultural views of natural resource management that may exist between different ethnic groups in the Amazon. The opposition between the
Lusura sp. caterpillar as pest and the Suruí view of them as a desirable food is practically irreconcilable. Not only in the Haugassen article, but also in the other entomological studies here referenced that were conducted in caboclo communities that seasonally collect Brazil nuts for sale, the Lusura sp. outbreaks are considered harmful to production (Hurtado 2010; Santos 2011). For the Suruí, who also consume and commercialize Brazil nuts harvested from their lands, the caterpillar outbreaks on Brazil nut trees are not interpreted in terms of loss. Although Brazil nuts may occupy a more significant position in the overall Suruí diet and economy, Lusura caterpillar outbreaks are valued as welcome moments of increased food diversity. From the Suruí perspective, they constitute pleasurable opportunities to spend days with one's family in the Brazil nut groves, taking advantage of a delectable food that is rarely available and largely unpredictable.

As I look back and reflect on my old Suruí field notebooks, it is apparent that the ethnobiological knowledge I recorded back in 1983 was very possibly already at risk of disappearing in the face of the rapid process of sociocultural change that confronted the indigenous peoples of Rondônia, especially that which occurred through the influence of the BR-364 highway, which was first paved that very year. Already at the end of my visit to the field in 1983, I speculated that possible factors influencing changes in the dietary behavior of the group, especially among the youth: “....were 'civilized' prejudices regarding determined foods, expressed in the manifestation of nausea or repulsion. This happens principally in relation to the consumption of insect larvae..." (Coimbra Jr. 1985:82). Despite this pressure, I sincerely hope that some Suruí might still enjoy mamnégey on the occasion of the next outbreak on Brazil nut trees in the region.

\section{Acknowledgements}

I would like to thank Ricardo V. Santos for reading my early drafts and James R. Welch for his insights and translation from Portuguese. Eduardo Pina kindly restored my old slides and photographic prints reproduced in this paper.

\section{References Cited}

Alves, R. R. N., K. S. Vieira, G. G. Santana, W. L. S. Vieira, W. O. Almeida, W. M. S. Souto, P. F. G. P. Montenegro and J. C. B. Pezzuti. 2011. A Review on Human Attitudes Towards Reptiles in Brazil. Environmental Monitoring and Assessment E-pub ahead of 
print:1-25.

Araujo, Y. and P. Beserra. 2007. Diversidad de Invertebrados Consumidos por las Etnias Yanomami y Yekuana del Alto Orinoco, Venezuela. Interciencia 32:318-323.

Coimbra Jr., C. E. A. 1984. Estudos de Ecologia Humana entre os Suruí do Parque Indígena Aripuanã, Rondônia. O Uso de Larvas de Coleópteros (Bruchidae e Curculionidae) na Alimentação. Revista Brasileira de Zoologia 2:35-47.

Coimbra Jr., C. E. A. 1985. Estudos de Ecologia Humana entre os Suruí do Parque Indígena Aripuanã, Rondônia. Aspectos Alimentares. Boletim do Museu Paraense Emilio Goeldi (Antropologia) 2:57-87.

Coimbra Jr., C. E. A. and R. V. Santos. 1993. Bicudo das Palmáceas: Praga ou Alimento? Ciência Hoje 16:5960.

Costa-Neto, E. and J. Ramos-Elorduy. 2006. Los Insectos Comestibles de Brasil: Etnicidad, Diversidad e Importancia en la Alimentación. Boletin de la Sociedad Entomológica Aragonesa 38:423-442.

Dufour, D. L. 1987. Insects as Food: A Case Study from the Northwest Amazon. American Anthropologist 89:383-397.

Haugaasen, T. 2009. A Lepidopteran Defoliator Attack on Brazil Nut Trees (Bertholletia excelsa) in Central Amazonia, Brazil. Biotropica 41:275-278.

Hurtado, G. B. 2010. Plagas en la Producción de la Castaña (Bertholletia excelsa H.B.K.) en la Amazonia Boliviana. Instituto Boliviano de Tecnología Agropecuaria/ Fundación Para el Desarrollo de la Provincia Vaca Diez, Riberalta, Bolívia.

Paoletti, M. G. and D. L. Dufour. 2005. Edible Invertebrates among Amazonian Indians: A Critical Review of Disappearing Knowledge. In Ecological Implications of Minilivestock: Potential of Insects, Rodents, Frogs and Snails, edited by M. G. Paoletti, pp. 293-342. Science Publishers, Enfield, NH.

Santos, R. R. 2011. O Extrativismo de Castanha-do-Brasil, Bertholletia excelsa (Humbl. \& Bompl.) no Rio Madeira, Rondônia: Bases para uma Gestão Ambiental Participativa. Unpublished Master's Thesis, Departamento de Hidrobiologia, Universidade Federal de São Carlos, São Carlos, Brasil.

Weller, S. J. 1992. Survey of Adult Morphology in Nystaleinae and Related Neotropical Subfamilies
(Noctuoidea: Notodontidae). Journal of Research on the Lepidoptera 31:233-277.

\section{Biosketch}

Carlos E. A. Coimbra Jr. is a professor of medical anthropology and public health at the National School of Public Health, Oswaldo Cruz Foundation, in Rio de Janeiro.

${ }^{1}$ Botanical nomenclature follows the Lista de Espécies da Flora do Brasil 2012 accessible at http://floradobrasil.jbri.gov.br/2012 (accessed on May 7, 2012).

${ }^{2}$ Caboclos are individuals of mixed indigenous and European ancestry.

${ }^{3}$ Although my ethnographic fieldwork among the Suruí Indians in Rondônia, Brazil, spanned two decades, the first phase entailed about four months each year from December 1979 to January 1984. During that time, my primary research interests were themes related to human ecology, diet, and health. 